História (São Paulo)

Antonio de Spinola in exile: the stay in Brazil

António de Spínola no exílio: a estadia no Brasil

\author{
Luís Nuno RODRIGUES \\ Lisbon University Institute, Lisbon, Portugal. \\ Contact: luis.rodrigues@iscte.pt
}

\begin{abstract}
The aim of this article is to analyze the life of General Antonio de Spinola during his exile, with a special focus on the period in which he lived in Brazil. The period of Spínola's biography analyzed in this article, therefore, is not the one in which he occupied the higher positions or the most important offices in his career. However, the exile in Brazil was an equally relevant period in his biography and this analysis allows us to monitor the political activity performed by the general during that period. Also it will bring some additional light to a particularly delicate period in the relations between Portugal and Brazil. In this text, we will therefore cross a biographical analysis with the concern in bringing new contributions to the history of the political activism of Portuguese opposition exiled in Brazil during the revolutionary period in Portugal and also to the history of Luso-Brazilian relations.
\end{abstract}

Keywords: biography; António de Spínola; exile.

Resumo: O objetivo deste texto é analisar o percurso do general António de Spínola durante o seu exílio, com especial incidência sobre o período em que residiu no Brasil. O período da biografia de Spínola analisado neste artigo, por conseguinte, não é aquele em que ele desempenhou os cargos mais elevados ou as funções mais importantes de sua carreira. No entanto, a estadia no Brasil foi um período igualmente relevante no seu percurso biográfico, e a sua análise permite acompanhar a atividade política desempenhada pelo general durante o exílio e, de igual modo, trazer alguma luz adicional a um período particularmente delicado das relações entre Portugal e o Brasil. Neste texto procura-se, por conseguinte, cruzar um registro eminente biográfico com uma preocupação em trazer novos contributos para a história das atividades políticas do oposicionismo exilado no período revolucionário em Portugal e também para a história das relações luso-brasileiras.

Palavras-chave: Biografia; António de Spínola; Exílio.

\title{
Introduction
}

The objective of this paper is to analyze the course of General António de Spínola during his exile, focusing on the period in which he lived in Brazil. First President of the Republic after the revolution of April 25, 1974 in Portugal, Spínola soon found himself embroiled in a political dispute with leftist sectors, which were the political, social and military forces opposed to the General's leadership and his plans for the future of Portugal. There was, in particular, an almost 
permanent climate of conflict between Spínola and the MFA (Armed Forces Movement). This dispute had its roots in the period leading up to April 25, 1974, but it steadily and gradually worsened in the months following the coup. The issue was not merely a clash of personalities. At the base of this "dispute", observes historian Maria Inácia Rezola, was the "profound contradiction" between the political projects of the two camps, both in terms of solution to the Portuguese colonial problem and configuration of the future political regime in Portugal. (REZOLA, 2006, pg. 52).

The increasing tension underwent many defining moments, culminating in Antonio de Spínola's resignation as President of the Republic on September 30, 1974. His resignation, however, did not result in withdrawal from Portuguese political and military life. In the months that followed, the general kept close contact with political and military personalities, trying to keep two possibilities open for his return to the spotlight: on the one hand, a legalistic means by which he tried to position himself as a potential candidate for President of the Republic, supported by parties to the right of the Portuguese Communist Party; on the other, via "coup d'état", betting on the support he still mustered from within the Armed Forces. Gradually, however, Spínola became skeptical of the legalistic strategy, instead drawing closer to the more radical sectors who advocated a coup d'état to reverse the political situation in Portugal, and who were betting on the figure of the general to lead the process. On the night of March 10 to 11, 1975, Spínola moved to Tancos Air Base, from where he set a military coup in motion. As we know, however, the operation resulted in a resounding failure, and "March 11th" witnessed the ready opposition of military units and political and social forces that were against Spínola. He was then forced to flee by helicopter to Spain, where he took refuge for a few days before continuing on to Brazil. (RODRIGUES, 2010, chapters 5 and 7).

Therefore, the period of Spínola's biography analyzed in this article is not when he held the highest office or played the most important roles of his career. In addition to President of the Republic after April 25, 1974, Spínola had played significant roles during the so-called New State, from command of the Portuguese military forces in Guinea-Bissau between 1968 and 1973, to Deputy Chief of Staff for the Armed Forces in 1974. The general had also achieved great notoriety earlier in 1974, with the publication of his famous book, Portugal e o Futuro (Portugal and the Future), in which he argued that Portugal's wars in Africa had no military solution and that the country needed to evolve towards constitution of a political community with its African colonies.

However, his stay in Brazil was an equally relevant period in his biographical journey, and its analysis shows the General's political activity during his exile and also sheds some additional light on a particularly delicate time in relations between Portugal and Brazil. This text will therefore cross an eminent biographical record with a concern for bringing new contributions to the history of 
political activities of exiled oppositionists during the revolutionary period in Portugal, and the history of Luso-Brazilian relations.

\section{A standstill in Spain}

The former President arrived at the Spanish air base of Talavera la Real late afternoon on March 11, 1975. In addition to the helicopter that brought him and his wife, another three helicopters carrying eighteen officers involved in the events of "March 11" also landed at Talavera. The Lisbon newspaper Diário de Notícias said that "all fugitives were under surveillance by the Spanish authorities, awaiting a decision from Madrid as to their fate”. (DIÁRIO DE NOTÍCIAS, 12/03/1975, p. 1-2).

Early on, however, there had been indications that Spanish authorities were unwilling to allow António de Spínola to remain in their territory, given that the former president's presence on Spanish soil could lead to misunderstandings and undermine the policy of anti-intervention in Portuguese affairs, defined by Spanish authorities. Indeed, on March 12, the Spanish government felt compelled to issue a statement denying any involvement in the events that occurred the day before in Portugal. The statement had become necessary in the wake of accusations and questions raised in Lisbon, and through it the Spanish government reaffirmed its "total adherence to the principle of non-intervention in the internal affairs of another state, a principle that had been strictly upheld and observed in its relations with Portugal." Although the document made no reference to the presence of Spínola in Spain, it clearly resulted from the former president's presence in Talavera la Real and from "the embarrassment to the Spanish government with Spínola staying in its national territory." The arrival of the former Portuguese president placed Franco's government in an "embarrassing situation, given the desire not to do anything that could be construed as a hostile gesture toward Portugal" and to prevent Spínola, while in Spain, "from becoming a unifying element of right-wing Portuguese exiles, who could create incidents along the border". (REPÚBLICA, 03/15/1974, p. 28).

Also, practically right after Spínola arrived in Spain, rumors emerged of the possibility of his moving to Brazil, including in Brazilian media. Quoted by Diário de Notícias, Rádio Jornal do Brasil announced that Spínola had requested political asylum with the Brazilian government. The news agency Cifra also reported that it was "very likely that General Spínola, his wife and eighteen Portuguese officials would be leaving Spain within the next hours to an unknown destination." Diário de Notícias quoted "usually well-informed sources from Lisbon", according to which the Spanish government would not grant political asylum "to leaders involved in the counterrevolutionary putsch". However, they would "facilitate transit through its territory to other 
countries, namely Brazil”. (DIÁRIO DE NOTÍCIAS, 03/12/1975, p. 2). In its issue on March 13, the newspaper República, also of Lisbon, announced further that the new Brazilian ambassador in Madrid, Sérgio Frazão, had been summoned to the Ministry of Foreign Affairs, "everything leading to believe that Franco's government will exert every effort to find a solution to the situation." (REPÚBLICA, 03/13/1974, p. 1).

The reasons for Spínola's choice of Brazil are not hard to understand. In addition to similarities in terms of language and culture, throughout the twentieth century Brazil had already established a tradition of welcoming Portuguese political refugees. In the first place, there was an extensive oppositionist community, whose most prominent figure would eventually become the presidential candidate of 1958, General Humberto Delgado. (PAULO, 2000). Following the persecution moved by the Salazar regime against Delgado, he had initially sought political asylum from the Brazilian embassy in Lisbon and then, with the aid of Ambassador Álvaro Lins, he had fled to Rio de Janeiro. More recently, however, Brazil had also received Américo Tomás and Marcelo Caetano, respectively the President of the Republic and Prime Minister of the Council of Ministers in the regime overthrown on April 25, 1974. Last but not least, Brazil had been under a dictatorship since 1964. President Ernesto Geisel had taken office in March 1974, and the conservative nature of his government made the country naturally "welcoming" for those fleeing the alleged revolutionary "excesses" in Portugal. Indeed, in the months following the change of regime in Portugal, Brazil's stance was not exactly the warmest, and with initial talk of "great uncertainty and near paralysis" in bilateral relations, and even "ideological bias" and "bilateral tensions" in the second half of 1974 and early 1975. The antagonism was mutual: Brazil was suspicious of the political developments in Lisbon, and "the Brazilian military regime, strongly conservative, inspired no empathy in revolutionary Lisbon". (CARVALHO, 2009, p. 56).

Beyond the ideological antagonism, bilateral relations between the two countries had further deteriorated with the appointment of Carlos Alberto Fontoura as Brazil's ambassador to Portugal, strongly contested by Portuguese authorities due to Fontoura having been head of the National Information Service, the publication in Brazil of the book Depoimento [Testimony], written by the former head of the Portuguese Government, Marcelo Caetano, and especially, for the manner with which Brazil had rushed to recognize the independence of Guinea-Bissau, before Portugal had even signed the independence agreement with the Guinea-Bissauan people, an act that had left Spínola himself on the verge of a nervous breakdown. (RODRIGUES, 2001, p. 423).

Upon Spínola's resignation from the Presidency, tension between the two countries deteriorated further. The Brazilian government and its diplomacy complained of the strongly critical references to the regime in force, including its comparison with Pinochet's Chile by certain sectors of the Armed Forces Movement (MFA), and the influx of Brazilian political refugees to Portugal, 
which increased after April 25. (FREIRE, 2010). Portugal was already apprehensive regarding the increasing drain of Portuguese capital into Brazil, the emigration of a significant number of Portuguese economic elites to that country, and Brazil's growing interest in African affairs, with international appeals for it to somehow play the role of mediator between Portugal and the nationalists of its former colonies. (CARVALHO, 2009, p. 63-78).

The issue of Brazilian expatriates in Lisbon was so sensitive in Brasilia that it turned out to be one of the main issues addressed by foreign minister Azeredo da Silveira on his visit to Lisbon in December 1974, which had been intended to clear the air between the two countries. Publicly, the chancellor made a point of stating that Brazil had never allowed "Portuguese exiles" to become a "factor of unrest", and that Brazilian authorities now expected Portugal to behave the same way in relation to Brazilian exiles. (CARVALHO, 2009, p. 102).

\section{Arrival in Brazil ... passing through Buenos Aires}

Because of all this, it came as no great surprise that Antonio de Spínola would abandon Spain to establish himself in Brazil. This came to pass on March 14, 1975, when the General, his wife and the officers who accompanied him departed aboard an Iberia flight to Brazil. However, his place of exile seemed, at this point, not yet fully defined, met with some initial reluctance by Brazilian authorities. Spain's Minister of Information and Tourism, León Herrera, publicly stated that Antonio de Spínola had left Madrid on an "ordinary aircraft" and that his "destination" as well as of those who accompanied him, would be wherever his respective political asylum requests were accepted." For the Franco government, Spínola's presence on Spanish soil was a "very serious annoyance", and one that had required immediate resolution. Furthermore, "consent had not been given for a press conference [...] precisely to reaffirm our intention of not allowing any interference in Portugal's internal affairs by anyone in Spanish territory". (DIÁRIO DE NOTÍCIAS, 03/15/1975, p. 13).

António de Spínola's arrival to Brazil would prove extremely problematic, given that Brazilian authorities had not been informed in advance of the Spanish government's decision. When Brazil's ambassador was received, at his request, by Spanish Foreign Minister Cortina Mauri on March 14, 1975, Spínola was already on his way to Brazil in an Iberia aircraft. The Brazilian government did not accept the "fait accompli", and therefore did not authorize the General and his traveling companions to land. According to a press release from Minister Azeredo da Silveira, his government had not been "consulted at any time about the Spanish decision, which [...] he only came to learn about later, and by his own initiative". ${ }^{1}$ 
Without authorization to disembark in Brazil, Spínola was forced to head to Buenos Aires. The trip to Argentina, still aboard the Iberia plane, took place on the morning of March $15^{\text {th }}$, and was extremely troubled. Spínola and his entourage arrived in Buenos Aires very "tense and anxious." However, he told an Associated Press reporter who had accompanied him during the flight that Brazilian authorities had assured him they would authorize his return to Brazil if he formally applied for a visa in Buenos Aires. However, despite these assurances, Spínola seemed seriously worried that, after his arrival in Argentina, the Brazilian authorities would go back on their promise. ${ }^{2}$ Nevertheless, the Argentine government had announced the granting of "asylum" to Spínola, but for a "transit period", a clear indication that his presence in Buenos Aires would also be temporary. (REPÚBLICA, 03/15/1974, p. 28).

Negotiations with Argentine authorities lasted about seventeen hours and were conducted inside the plane carrying General Spínola, since he refused the facilities offered by the Argentine authorities in an airport hotel. The Ministry of Foreign Affairs sent its Chief of Protocol to meet Spínola to liaise between the former Portuguese President and the Argentine Minister Alberto Vignes. The latter, in turn, stayed in frequent contact with the Brazilian ambassador in Buenos Aires. By late afternoon, the Brazilian Ambassador went to the airport to receive written statements from Spínola and the officers accompanying him, which assured that they would engage in any political activities during their exile in Brazil. Spínola and his entourage agreed to this imposition and the Brazilian ambassador informed the press on that same day that the Portuguese group would return to Brazil. ${ }^{3}$

On a side not, if the Brazilian authorities refused to authorize his return, Antonio de Spínola's plan B would have been to travel to Santiago, Chile. On the night of March 14, the ambassador of the United States of America in Santiago was informed by the Chilean Minister of Foreign Affairs that President Augusto Pinochet would grant political asylum to General Spínola, if Brazil and Argentina refused to do so. According to the Chilean minister, Spínola's arrival in Chile could take place in the coming days, and his government was aware of the possible consequences, including the severance of diplomatic relations with Portugal. ${ }^{4}$

However, negotiations with Argentine and Brazilian authorities were successfully concluded, and on the night of March 15, Spínola finally arrived in São Paulo, completing the last leg of his journey into exile. The arrival in São Paulo, reported Diário de Notícias, was also surrounded by heavy security. The police "kept reporters away from the arrival lobby of the airport and building lights were turned off so that the Portuguese refugees would not be seen." Spínola was promptly transferred to a Brazilian military aircraft, which shortly thereafter took flight to a military airport. A "parade of official vehicles drove him from the airport to a large hotel in the center of town - the Jaragua - where he would find temporary accommodations, and to which significant 
Brazilian police forces had already been deployed." Despite the security apparatus, on March 17 the newspaper Diário de Notícias revealed all the details, saying that Spínola was accommodated in apartment 1709, on the 17th floor of the hotel, one of the most "luxurious" in São Paulo, where the day rate cost up to 700 cruzeiros, i.e. over 2000 escudos, in the currency at that time. His companions were accommodated on the same floor, with the Brazilian police "having requested the remaining rooms on the floor.” Spínola would remain in São Paulo for a week before deciding on where to establish his future residence. (DIÁRIO DE NOTÍCIAS, 03/17/1975, p. 1, 10).

\section{From São Paulo to Rio de Janeiro}

General Antonio de Spínola then decided to leave São Paulo to settle in Rio de Janeiro, as he had initially desired. Journalist Dennis Redmond from Associated Press had accompanied Spínola on the trip to São Paulo. The General confided at the time that his future plans had not yet been defined, but that he would continue "to read and write as he had always done." However, he intended to start a "new life" in Brazil, a country which he had never visited. Throughout the conversation, Spínola made "frequent pauses" to make sure that he was honoring the "commitment" undertaken with Brazilian authorities to refrain from "political commentary" and refused to answer "specific questions about reasons for the lack of popular support for his attempted coup". (DIÁRIO DE NOTÍCIAS, 03/17/1975, p. 10).

He arrived in Rio de Janeiro on March 19, 1974, on a Brazilian military aircraft. At Galeão airport a "significant security force" had been deployed to receive the former Portuguese president. According to newspaper Diário de Notícias, "without removing the monocle on his right eye and wearing an elegant brown suit, the general, smiling and apparently very much at ease, settled immediately into the official car that would take him to the Grand Hotel Glória in the center of town, his temporary residence in Rio". (DIÁRIO DE NOTÍCIAS, 03/20/1975, p. 9). However, Spínola first went to a room reserved by the authorities to meet some journalists. There, he kept his word not to make public statements, and limited himself to answering their questions "with evasive answers, sometimes very softly, almost inaudibly, and sometimes just shaking his head". (DIÁRIO DE NOTÍCIAS, 03/21/1975, p. 9).

On the previous eve, Diário de Notícias had already stated that Antonio de Spínola would take up residence in Rio de Janeiro, as would the military people with him. For the moment, the Portuguese exiles were "guests" of the Brazilian government during the days that followed until the conclusion of "legal residency formalities" by the Ministry of Justice. However, Carlos Lacerda, journalist and former governor of Guanabara, who had published Portugal e o Futuro in Brazil, had already received Spínola and told the newspaper Jornal da Tarde that the general was "determined 
to continue the fight." Newspaper O Estado de São Paulo in turn indicated that "some diplomats believe that although the grant of asylum could be exploited by some sectors in Portugal, it would not damage Brazil's relations with that country". Spínola and his supporters, according to the "rules" of asylum, could not engage in any political activity in Brazil. At the same time, they were "sufficiently distant" from Portugal to constitute a "major threat" to the Portuguese government. "Worse for the Portuguese Government" the paper pointed out, "had they remained in Europe". (DIÁRIO DE NOTÍCIAS, 03/18/1975, p. 8).

In his first night in Rio, Spínola met with Carlos Lacerda, who placed at Spínola's disposal his "luxury villa in Teresopolis, a summer resort location nestled in the mountains surrounding Rio de Janeiro". (DIÁRIO DE NOTÍCIAS, 03/20/1975, p. 9). Moreover, outside the hotel, Carlos Lacerda revealed that Spínola had received thirty-four thousand cruzeiros in royalties for the Brazilian edition of Portugal e o Futuro. (DIÁRIO DE NOTÍCIAS, 03/21/1975, p. 9).

However, at the end of March in Portugal, the Revolutionary Council decided to expel António de Spínola from the Portuguese armed forces, along with the remaining officers involved in the March 11 attempted coup. The reason invoked was that they had been "the masterminds behind the counter-revolutionary coup", having "failed" in their "responsibilities" and fled the country. Furthermore, the Revolutionary Council considered that in the "counter-revolutionary attempt" of March 11, the perpetrators had caused "the fratricidal confrontation among the military, with the clear intent to cause an immediate division between members of the Armed Forces." The expulsion had several consequences: "The suspension from exercising political rights for a period of twenty years; loss of the right to wear military medals, honors, and to receive rewards or pensions for past services, and barring from military service”. (DIÁRIO DE NOTÍCIAS, 03/25/1975, p. 9).

On March 26, 1975, Antonio de Spínola decided to send a letter to the Brazilian president, General Ernesto Geisel. Spínola thanked him for the "kind hospitality" granted by the Brazilian authorities in the "difficult times faced by the Portuguese homeland" and for Geisel's "direct intervention" in the whole process. He later sought to justify the events of March 11, presenting them as "a last resort to prevent the establishment of a communist regime in Portugal." He also accused the Portuguese Communist Party (PCP) of having, "through a clearly identified conspiracy", prepared a "list of people to be physically eliminated, including senior army officers and civilians of economic, financial and intellectual prominence." Spínola had been warned of the plan's existence through the Spanish "Joint-Chiefs" and the French "secret service", and had decided to act. Hence the "coup" was intended to "protect the democratic postulates that led to the military uprising of April 25". 
With Spínola in Brazil, Luso-Brazilian bilateral relations further deteriorated. This was due not so much to the General's presence on Brazilian soil, but to radicalization of the political situation in Portugal after March 11th. At this stage of the so-called "Gonçalvismo"6 state that "the diplomatic ties would deteriorate to almost total paralysis." Concurrently, it continued to aid the relocation of Portuguese economic elites to Brazil, who were "fleeing the uncertainties and the radicalization of the revolutionary process" and the increasingly critical positions taken in Portugal in relation to the Brazilian regime. As reported by historian Thiago Carvalho,

on a nearly daily basis the Portuguese press denounced the censorship imposed on Brazilian communication agencies, the torture and political persecution, the opposition from hard-line regime to liberal reforms, the criticisms made by the Church against repression.

In June 1975, VARIG's facilities in Lisbon were also attacked with explosive grenades. (CARVALHO, 2009, p. 104-109).

\section{Exile and creation of the MDLP}

The experience of exile was a harsh reality for Antonio de Spínola. In the space of little over a year, the general had gone from true "national hero", protagonist of the biggest political changes seen by the country in the last fifty years, to a political exile in Brazil. In an interview with the EFE agency's correspondent in Rio de Janeiro, in early August 1975, Spínola said:

exile for me has proved valuable, as a period of reflection on the experience, and especially, about the origins of serious deviations from the Portuguese Revolution, which sought to build a democratic Portugal, in line with Western Europe.

A few days later he recognized, in another interview: "Like any self-respecting Portuguese man, I feel bitter about the situation in my country." In Brazil, Spínola said he kept "an active intellectual life by reading, writing, watching "pari passu the day-to-day life of the people to which I belong", and musing "about his future". When asked about "future plans" and about longing for the "homeland", Spínola replied that his plans were "those of any Portuguese who has not given up on seeing peace, freedom and justice brought to Portugal" and of "living in a truly free, just and sovereign Portugal”. (SPÍNOLA, 1976, p. 251; 259; 271).

In any case, contrary to the assurances he had given to Brazilian authorities, the general remained politically active during his stay in Brazil, and played a prominent role in the creation and consolidation of a political-military movement to resist the political developments in Portugal, 
namely the alleged establishment of a "communist dictatorship" underway in the country. This was the Democratic Movement for the Liberation of Portugal (Movimento Democrático para a Libertação de Portugal - MDLP), created in May of 1975, on the initiative of a group of Portuguese exiles in Spain, in which Alpoim Calvão, José Miguel Júdice, José Valle de Figueiredo and Marques Bessa pontificated, among others. The goal would also be to create a common front that could unite Portuguese exiles in Spain and Brazil under the leadership of General Spínola, to enable a reversal of the political situation in Portugal. (BERNARDO, 2004, p. 356).

The proposal to create the movement was sent to Spínola in early May, 1975. The general promptly responded, agreeing to lead the movement and proposing the name of MDLP. The matter had been "largely deliberated and resolved based on the advice of Dr. Carlos Lacerda, a man of exceptional political experience". Spínola felt that the document was "perfect", without the need for "any amendments". It was therefore "ready to be disseminated at opportune moment, when the different political forces had gathered." At this time, "I should be notified so as to simultaneously disseminate it in Brazil”. (DÂMASO, 1997, p. 237-239).

Spínola thus engaged personally in creating the MDLP, and more than that, he did not hide it from the Brazilian authorities. On May 13, 1975, he met with the director and deputy director of the Information Center of the Brazilian Navy, at the home of Brazilian jurist Clóvis Ramalhete. In the meeting, the general hinted very clearly that he was determined to carry out "a project of revolutionary characteristics, whose purpose would be to overthrow the current Portuguese government." To do so, he told the Brazilian military, he intended to trigger within the country "a subversive action, much like those recommended by the Soviet Union, which could even involve guerrilla action." Spínola said that other nations, not specified, were "in tune with his plan", and that "various forms of aid were already being studied and/or placed at his disposal." However, the general could not understand why he had yet to be "approached" by Brazilian government officials, even if only to expose his intentions, and felt "completely isolated, in a position of true captivity" in a country where not even a passport had been granted to him. This latter issue was particularly sensitive. Spínola wanted a Brazilian passport because of the "urgent need to travel for absolutely confidential visits to representatives of foreign governments". 7

\section{International action}

The aforementioned assiduousness seemed to have an effect, and on May 23, 1975, Spínola managed to get his Brazilian passport (THE NEW YORK TIMES, 05/24/1975, p. 7), which enabled him to go to France in July of that year. The Portuguese and Brazilian media reported his presence in Paris to "organize opposition against the Portuguese regime." A "spokesperson" for the former 
Portuguese president admitted in Rio de Janeiro that his visit to Europe was "to negotiate unification of the opposition against the current Portuguese government". The Brazilian Government had been aware of Spínola's travels, having arrived at Galeão Airport "without his famous monocle, wearing sunglasses and clothing unlike his customary apparel". (DIÁRIO DE NOTÍCIAS, 07/23/1975, p. 1; 8). Also, the U.S. embassy in Paris had received information that Spínola had traveled to France, despite not knowing the "exact details" of his visit. The general would have first gone to Geneva to then enter France without the knowledge of French authorities. Spínola had a Brazilian passport, therefore not requiring a "French visa" for a "temporary visit".

In France, Spínola met with Count de Marenches, of the French secret service. However, the meeting turned out to be disastrous for the general's ambitions. Trying to convince his interlocutor on the size and capacity of his support, and the forces at his disposal, Spínola depicted an unrealistic picture of a potential invasion of Portugal by armies led by him. According to statements by Sanches Osório, a military officer close to Spínola and exiled in Paris, this plan by the MDLP was "completely megalomaniacal", and it eventually led the French to withdraw any "effective support." Sanchez Osório also organized a meeting between the former Portuguese President and some potential financiers of the MDLP. The meeting took place at the home of Portuguese businessman Manuel Boullosa in Neuilly, near Paris, attended by two other businessmen, Miguel Quina and António Champalimaud. The latter, however, walked away from Spínola's organization right from the first meeting because he "did not believe in General Spínola" and considered him "rather unfit for politics". (DÂMASO, 1997, p. 54-57).

\section{The "hot summer" of 1975}

Throughout the summer of 1975, political tensions in Portugal heightened, the bloc led by the Socialist Party and the "moderate" military, however grouped around the so-called "group of nine", opposed the bloc represented by the Portuguese Communist Party and the leftist military. Spínola then decided, from Brazil, to write an open letter to the President of the Republic, General Costa Gomes, claiming to have confirmed "all prospects I foresaw when I warned the Portuguese about the consequences of the criminal 'scorched earth' policy that a group of traitors had in mind to establish a communist state over the ruins of a razed Portugal". In a "time of pride due to the sublime example of combativeness and patriotic spirit demonstrated by our martyred people", Spínola launched an appeal "to the brave civilian combatants and my brothers in arms [...] for us to unite around the Democratic Movement for the Liberation of Portugal, which intends to rebuild the homeland based on the reconciliation of all Portuguese people, in freedom, dignity and justice". (SPÍNOLA, 1976, p. 263-265). 
This open letter from Spínola, and the general's successive public statements, ultimately aggravated the ill will between Portuguese and Brazilian authorities, given that the former Portuguese President had promised not to make statements of a political nature while exiled in Brazil. A spokesperson for the Portuguese embassy in Brasilia told the press that Spínola's actions could create "major difficulties" in relations between Portugal and Brazil, whereas the General's letter to the Portuguese president was, in itself, an act of "disrespect" by Brazilian authorities. It was now up to Brazil to ascertain whether the "international rules" that regulated Spínola's presence in the country would be met. The general, however, had clearly "abused the Brazilian hospitality and ignored the responsibilities he had committed to with the Brazilian government". In fact, the U.S. ambassador in Brasilia also confirmed that the Brazilian government's apparent "tolerance" had raised some "speculation" in North American press. It was possible that Brazilian authorities had allowed and even "encouraged" Spínola's activities in response to the "acquiescence" by the Portuguese government for the political activities of "Brazilian dissidents" in Portugal. A member of the Ministry of Foreign Affairs informed the U.S. Embassy in Brasilia on August 22 that the Brazilian government had formally protested several times against the activities of Brazilian exiles in Lisbon or the "hostile treatment" from the Portuguese press. The Brazilian diplomat also denied that Spínola had been "encouraged" by the Brazilian government as it had "nothing to gain" and "a great deal to lose" if it allowed Portuguese political conflicts to extend to Brazilian territory. The U.S. ambassador also asked whether the Brazilian government intended to "reprimand" Spínola for the letter to Costa Gomes. Itamaraty's deputy replied that it was up to the Minister of Justice to "monitor political exiles," but noted that "technically" Spínola's letter had been published in France and not Brazil. Either way, a public statement was to be expected soon from the Brazilian government with a "mild public reprimand" of Spínola, reminding him in general of the obligations of political exiles in Brazil. ${ }^{9}$

On August 23, the Brazilian foreign minister, Azeredo da Silveira, took the opportunity during a public speech to reaffirm that his government was "strictly complying with the principle of non-interference in the internal affairs of other countries." More than a reprimand to Spínola, Silveira was concerned with reminding, in a clear allusion to the negative treatment that the Brazilian regime was shown in some Portuguese newspapers, that the principle of non-intervention was only one side of a coin whose other face was respect, where anyone failing to respect should not expect to be respected, and those who intervene should not complain about interference. At any rate, Brazil wished to "avoid the transfer into our country of the domestic political passions in other nations, strange passions, regardless of which emotional sides unite us with other peoples, our national problem". ${ }^{10}$ For U.S. observers, Silveira's words represented a moderate public reprimand and an official reminder directed not only at Spínola, but other Portuguese political exiles, 
regarding their obligation to avoid acts that could embarrass the Brazilian government and violate their condition of exile. At the same time, it was a direct allusion to the fact that the Brazilian government expected the same type of behavior from Portuguese authorities with regard to Brazilians living in Portugal as exiles. ${ }^{11}$

Not satisfied, the Portuguese embassy in Brazil found it proper to submit an official protest to the Brazilian government. In a letter dated August 30, 1975, the Portuguese diplomat drew attention to statements by António de Spínola about the political situation in Portugal, recalling that when granting asylum to the General and other officers of the Portuguese Armed Forces, the Brazilian authorities had always clearly indicated their unwillingness to allow former general Spínola or his entourage any activities or public statements of opinion that could call into question their status as political exiles, and the Brazilian government's reiterated intent to remain faithful to the principle of non-interference in the internal affairs of countries with whom it cultivated friendly relations. Therefore, the Portuguese government declared itself surprised at the frequent interviews made by Spínola in Brazilian territory. It was serious that Spínola had given such interviews, apparently enjoying full impunity, but it was even more disturbing that his statements revealed that in recent months he had been developing in Brazil, or from it, a whole set of activities of political character, entirely irreconcilable with the guiding principles of Brazilian foreign policy. The Embassy of Portugal lamented that a Portuguese political individual, with the duties of former General Spínola, had thus taken a stance against the principles of non-interference and opposition to all forms of terrorism, which the Brazilian government had clearly advocated as the basic directives of its foreign policy. The Portuguese government warned against the nature of Spínola's activities and the serious damage they would inevitably inflict on Luso-Brazilian relations, should he be allowed to continue. $^{12}$

The open letter from Spínola to Costa Gomes had just been the last straw to break the camel's back. In the preceding weeks, the general had made statements about the situation in his country, precisely at the time when a strong popular anticommunist movement was stirring in Northern Portugal, characterized by acts of political violence against the offices of left-wing political parties of the Socialist Party and offices of several labor unions. These almost daily assaults were large-scale, with the destruction of equipment and furniture, and usually with bonfires burning the spoils. Although the popular mobilization was called the movement of Maria da Fonte, organized in Portugal by Paradela de Abreu, the MDLP was clearly involved in episodes of political violence that took place in the north of the country. (CEREZALES, 2003, p. 141-155).

Spínola's successive declarations were seen in this context. The General considered the events in Portugal a true "national resurgence [...] most eloquent proof that the Portuguese people demand a revolution that implements a participatory, social and representative democracy, contrary 
to all forms of imperialism, dictatorship and oppression". In an interview with The Associated Press in Rio de Janeiro, Spínola made his thoughts on the MDLP explicit. It was a "single front of resistance fighting against the Marxist dictatorship established in my country". It essentially acted "within" the country and carried out its activities "very harshly, given that those we disagree with the current regime were not allowed free political expression". (SPÍNOLA, 1976, p. 246; 257-258; 269-270).

Despite protests from Portuguese diplomats, Spínola's statements continued throughout the month of September 1975. The general showed no interest in curbing the exaltation of MDLP militants and other political groups acting in the north of the country. At a certain point, in an interview, he stated that if they did not give "opportunities for the masses to express themselves peacefully and successfully against the violence they suffered, they would have no choice but to answer communist violence with anti-communist violence". Therefore, there would be no other solution except to "respond to violence with violence in order to neutralize the forces of oppression". (SPÍNOLA, 1976, pg. 297).

\section{New trip to Europe}

At the height of political and social conflict in Portugal, General Antonio de Spínola decided to embark on a new tour of Europe in his relentless quest for international support for the MDLP. Leaving Rio de Janeiro, Spínola landed in Paris on the night of September 3, 1975, with his arrival in France widely publicized by the Portuguese press. Spínola's visit to Europe at the beginning of September was justified by several reasons. The leader of the MDLP sought to consolidate the movement, mobilize support and recruit new members, establish contacts with politicians and "moderate" military elements, and potentially take the first steps in preparing a large-scale operation to commence in northern Portugal: the so-called "Spinolist invasion." The French press claimed that during his stay in Europe the general would "try to recruit the Portuguese living abroad, especially among refugees, into his MDLP". He would also seek "among the wealthy members of Portuguese communities with whom he maintained ties, funding for his movement". All of these activities would take three weeks, after which they would phase into "broader action" in Portuguese territory. (REPÚBLICA, 09/04/1975, p. 2).

Also, Radio Jornal do Brazil denounced the political and operational nature of the general's journey, referring to reports that "international brigades that the former Portuguese president was gathering would move into action within three weeks". All of this information had gained renewed prominence in Brazil, since Spínola's friend and supporter, Carlos Lacerda, had stated that the Portuguese opposition was just waiting for "someone able to coordinate its action", also implying 
that this was Spínola's “mission”. (DIÁRIO DE NOTÍCIAS, 09/08/1975, p. 2). Both the U.S. embassy in Paris and the French Communist Party's newspaper, L'Humanité, confirmed this idea. The embassy said that Spínola tried to be as close as possible to Portugal, because "he had been told by friends in Lisbon that he should [...] remain prepared to take advantage of the anticipated rebellion", ${ }^{13}$ while the newspaper assured that the general's objective was to establish a "base of operations" in Europe. (DIÁRIO DE NOTÍCIAS, 09/08/1975, p. 2).

Thus, Spínola's activities in Paris were also not seen favorably by the French government which, according to the U.S. embassy, did not wish for Spínola to stay too long in that city, which is why the General would soon leave the French capital. ${ }^{14}$ In a brief press release, Spínola hastened to confirm that "he would soon return to Brazil after completing his personal visit", not corroborating the news that he would "settle" in Madrid. (DIÁRIO DE NOTÍCIAS, 09/08/1975, p. 2).

Spínola's activities were closely followed by the U.S. ambassador in Lisbon, Frank Carlucci, who had also served in Brazil at the time of João Goulart's overthrow. Closely watching the movement of the Socialist Party and the military gathered around the "group of nine", Carlucci believed that Spínola's movements could not have come at a worse time. If the former Portuguese president moved forward now, Carlucci advised Washington, with a hypothetical invasion force in northern Portugal, we would not have any chance of success as, from one moment to the next, it would undermine the progress made so far toward restoring some balance in the Portuguese political scene. Spínola's widely publicized activities in Paris had become a real obsession in Lisbon, clearly working in favor of the PCP's interests, which now accused moderate civilians and military of conspiring with Spínola for a coup by the extreme right. The ambassador strongly recommended that the United States inform its allies, particularly France, Spain and Brazil, that it did not support Spínola's plans and activities, which at that point in time were undermining Western interests in Portugal. ${ }^{15}$

The State Department did not hesitate to follow Frank Carlucci's advice. On September 12, a message sent by Henry Kissinger to his deputy, who was on a working visit to Sweden, recommended that should the Swedish Prime Minister, Olof Palme, dwell upon the figure of Antonio de Spínola and on Portuguese groups in exile, the second in command at the State Department should reaffirm Ambassador Carlucci's position. That is, the U.S. government considered that any act by Spínola in Portugal at this time was not only doomed to fail, but it would also favor the position of radical leftists and Communists, thereby undermining the gains that moderate forces had apparently achieved in the preceding week. ${ }^{16}$ The next day, Kissinger would in fact order the circulation of a message at several U.S. diplomatic posts, essentially conveying Carlucci's recommendations. Some groups of Portuguese exiles in Spain and Brazil had come together under the nominal leadership of former President António de Spínola and formed the 
MDLP. According to press reports and testimony from Portuguese authorities, the MDLP could be on the verge of developing some type of military operation in Portugal. The United States, Kissinger reinforced, was neither aware of such plans by this Movement, nor the size of its financial support and military capabilities. It agreed with the analysis of its ambassador in Lisbon that any type of deployed Spinolist operation would, at this point, be doomed to failure. Any action by the MDLP in Portugal or abroad, under the present circumstances, would ultimately aid the attempts of communists and left-wing radicals, thereby jeopardizing the gains moderate Portuguese citizens had achieved recently. In any discussions with authorities in the respective countries, U.S. ambassadors were to make their government's position clear, as expressed in this telegram. ${ }^{17}$

\section{Return to Brazil}

On September 13, General Antonio de Spínola would return to Rio de Janeiro. Soon after his return, the Portuguese ambassador in Brasilia, Vasco Futscher Pereira, visited the Ministry of Foreign Affairs. According to Diário de Notícias, the ambassador's visit was directly linked to the figure of General Spínola. Fuscher Pereira formalized a new protest from his government against the "hostile statements recently directed at the Lisbon regime by former General Spínola in Brazil". (DIÁRIO DE NOTÍCIAS, 09/15/1975, p. 2).

In addition to Portuguese diplomatic efforts, the U.S. embassy in Lisbon also remained particularly concerned about the actions of Antonio de Spínola. On September 17, Frank Carlucci wrote directly to his counterpart in Brazil reinforcing all of his previous recommendations concerning General Spínola. The general's main contacts in Brazil, Carlucci affirmed, included Carlos Lacerda, Armando Falcão and Nina Ribeiro, all well acquainted with Carlucci during his stay in Brazil in the previous decade. The ambassador in Brasilia could use Carlucci's came when speaking with these three personalities and directly mention his "personal opinion" about Spínola, as he believed they would give "some credit" to his opinions. ${ }^{18}$

However, despite Portuguese and American diplomatic efforts, Spínola did not hold back in his public statements about the situation in Portugal. Still during the month of September, the general said that the "political course will be violently altered if those presently in power persist in the violence inflicted on the Portuguese people". Spínola said that the Communist Party and organizations of the extreme left "could be banned under a new democratic regime", if they continued to act as they had been. He also commented on his recent visit to Europe, affirming to have maintained "contact with all those who could contribute to a correct perspective of the Portuguese situation". Those who were "able to do so" stood at "various political levels" that Spínola would not reveal "for security reasons". (DIÁRIO DE NOTÍCIAS, 09/23/1975, p. 3). 
Later, in October, General Spínola sent a message to the UN Secretary-General, the UN High Commissioner for Refugees, the President of the International Red Cross, and the President of Caritas, warning of the danger of political developments in Portugal. In this message, Spínola reaffirmed his "purpose" in Portugal to establish an "authentic democracy", seeing fit to portray "the state of mind of a people who have been witnessing constant violation of their most basic rights, and watching in agony as the last hopes of freedom, dignity and justice go up in smoke". All of this was due to the action of the Portuguese Communist Party and "other Stalinist groups, which, along with a group of officers, had led Portugal to the moral, social, economic and political catastrophe that it is in today". Spínola was thus making "heartfelt appeal to responsible Western leaders, humanitarian associations and international organizations to come to the aid of Portugal and Angola, freeing the people of these two countries from the clutches of totalitarianism". (SPÍNOLA, 1976, p. 309-310).

A few days later, on November 4, 1975, Antonio de Spínola gave another interview in Rio de Janeiro, this time to the Spanish magazine Cambio 16. The general now commented on the action of the new interim government in Portugal, led by Admiral Pinheiro de Azevedo since September 19, 1975. This government, supported by moderate portions of the Armed Forces, the Socialist Party and the People's Democratic Party, marked the end of "Gonçalvismo" but a few days after taking office, it was faced with great social and political upheaval from leftists. Spínola promptly accused the new leader of not having "the authority or the strength required to achieve the democratic goals it proclaimed": the government might even have "good intentions", but found itself overtaken by the "seriousness of the political, social and economic situation" in the country. (SPÍNOLA, 1976, p. 315-318).

\section{Visit to the USA}

It was in this context that General Antonio de Spínola began preparing a trip to the United States in order to garner support and spread his message to Portuguese communities and U.S. authorities. On November 13, 1975, the State Department informed the U.S. Embassy in Lisbon that Spínola planned to visit New York, Boston and Washington. The general had already scheduled a "breakfast" with journalists at the National Press Club, a meeting with officials of the Senate Foreign Relations Committee, and an interview with journalist Tad Szulc. In New York, Spínola also intended to address the Overseas Press Club and the Council on Foreign Relations. Even then, there were no details about the visit, but the State Department was of the opinion that the general would do everything in his power to achieve wide media coverage. ${ }^{19}$ 
Spínola's visit to the United States would take place, again, during a particularly turbulent period in Portugal. Throughout the first half of November, the positions of moderates and radicals had become extreme. On day 6, Mário Soares and Alvaro Cunhal, leaders of PS and PCP, engaged in a heated televised debate in which the differences between the two leaders, their parties and their political plans had become, more than ever, greatly pronounced. The very next day, the government ordered the destruction of Rádio Renascença's transmitters, occupied by elements of the extreme left. On November 9th, there was a large convoy supporting the government led by Pinheiro de Azevedo, and on the 12th, São Bento Palace was surrounded by construction workers, keeping members of Parliament retained in the Chamber.

In light of this situation, the U.S. government feared the possible impact of Spínola's presence in the United States on Portuguese public opinion, because of which it was ready to exert every effort to minimize this impact. The State Department had persuaded the Washington Institute of Foreign Affairs not to invite Spínola, and had taken measures to prevent the former Portuguese president from being received by any member of Gerald Ford's administration. It could not, however, keep staff of the Senate Foreign Relations Committee from receiving the general. At the time, Henry Kissinger believed that further efforts to restrict contacts by Spínola in the United States would not be advantageous, as the situation could draw even more attention to his presence on American soil. The Secretary of State instructed the U.S. ambassador in Lisbon to exert every effort to minimize the damage that could result from Spínola's visit, informing Melo Antunes, of the "group of nine", Mário Soares and Carneiro, the PPD leader, about the general's plans and the negative reaction from the U.S. government. The ambassador was to emphasize the fact that representatives of the executive branch would not meet with Spínola and remind the Portuguese about the open nature of American society. In effect, Spínola had made a similar visit to France a few weeks before. ${ }^{20}$

In Lisbon, however, it was difficult to explain the nature of Spínola's trip to the United States and the contacts he would make. On day 15, ambassador Carlucci reported to Washington that he had informed the Portuguese government, the PS and PPD of Spínola's visit to the United States. In his opinion, the parties and the government did not easily understand the distinction between the executive and legislative branches in the American political system, or the difference between Senate staff and the Senate itself. ${ }^{21}$ Carlucci would also raise the issue with the President of the Republic, Costa Gomes. He proved to be "more comfortable" with the fact, though he claimed that the former president was greatly to "blame" for the problems that Portugal was going through. However, he was convinced that there was no possibility of a Spínola comeback, in political and military terms. $^{22}$ 
The State Department at first chose to release a statement about Spínola's visit to some governments considered more relevant in this context, such as Brazil, France and Spain. On November 18, the U.S. embassy in Madrid informed the Ministry of Foreign Affairs of Spínola's planned trip and explained that the U.S. government was in no way involved with the visit. The Spanish authorities agreed that Spínola's visit to the United States could not have come at a worse time, as it could be used by Portuguese leftist elements to demonstrate that forces abroad were committed to nullify the results of the revolutionary military coup of April 25th. The Spanish government also had information that in recent days the forces for Vasco Gonçalves were getting organized for a final attack on the government of Pinheiro de Azevedo. ${ }^{23}$ A similar message was also sent to the Brazilian government on November 18. On that day the first news of Spínola's visit to the United States had come out in the Brazilian press. ${ }^{24}$ In France, the Quai d'Orsay expressed interest in being informed about the former Portuguese president's visit and forming a proper interpretation of that visit. ${ }^{25}$ Following the advice of the U.S. Ambassador in Lisbon, the State Department had also prepared press guidance regarding António de Spínola's visit to the United States. In response to any questions from the media, the State Department's media liaison would claim that Spínola's visit was private and that the general was not in the United States on the initiative of the U.S. government which, moreover, had played no part in the preparation and organization of the visit. There were no plans for members of the Executive branch to receive the General during his stay in Washington. If questioned, the liaison would also publicly assure that the U.S. government was not assisting General Spínola. ${ }^{26}$

During his stay in U.S. territory, where he arrived on November 17, Spínola engaged in contacts, interviews and conferences, from the University of Connecticut-Storrs to the Council on Foreign Relations in New York, giving an interview to journalist Susan Fraker of Newsweek or to the Portuguese Times newspaper published in New Bedford. There were also frequent Sessions with Portuguese communities, such as at Symphony Hall in Newark, and even a visit to Toronto, Canada.

\section{The impact of November 25, 1975}

Antonio de Spínola followed the events surrounding the military coup of November 25th with natural anxiety. In his view, it was a "very important step" in the military and political life of the country, given that it allowed for containment of "anti-democratic forces that compromised the democratization process that April 25th had intended to establish, consolidate and develop". (SPÍNOLA, 1976, p. 382-383). Early in December, in a statement issued by his "aids" to the press in Rio de Janeiro, the general stated that "the Communists had failed in Portugal and the country 
might soon find the path to democracy". The development would now depend on the "lucidity and determination" of "military democrats", who would need to "continue their valuable work". (A LUTA, 12/04/1975, p. 16).

November $25^{\text {th }}$, however, came at the worst time for the intentions of Spínola and his followers. The MDLP had been particularly active in garnering international support and mobilizing its supporters, preparing to expand its scope of action through a direct intervention in Portuguese territory, using a significant amount of available weaponry. This was at least an intended faction within the MDLP, one that would always favor the creation of a "liberating" army on Spanish soil. (DÂMASO, 1997, p. 37-42).

At this point, however, assessing developments in Portugal, Spínola had begun to prudently move away from the faction advocating the "great invasion", concerning himself since mid-October with "centralizing" leadership of the MDLP in his hands. In an attempt to remedy the differences that had become more pronounced within the Movement itself, on October 16, 1975, Spínola issued a directive prohibiting any member of the organization from making "public statements without prior authorization from the Presidency", and claiming that only he was fit "to designate which agencies and elements could carry out the information policy, and the measures best suited to express the image of the MDLP". (CALVÃO, 1976, p. 222).

Shortly after the events of late November in Lisbon, António de Spínola decided to travel to Spain to be in direct contact with MDLP leaders there and to plan future actions of the Movement. Spínola's trip this time was detected by a journalist from the Spanish magazine Sábado Gráfico, who recognized him at Orly airport in Paris, precisely when he was embarking for Madrid. General Spínola arrived in the Spanish capital on December 8, wearing sunglasses and leaving Barajas airport without passing through "passenger checkpoints". (REPÚBLICA, 12/18/1975, p. 4). However, at this stage, after stabilization of the political and military situation in Portugal, Spínola's international position had become increasingly untenable. A few days after arriving in Madrid, Spínola was expelled by the Spanish government.

In any case, the meetings in Madrid in early December had allowed him to reflect on the new role of the MDLP and prepare a set of documents related to its reorganization and redefinition of its objectives. According to a new Directive, signed by the general himself on December 11, 1975, armed action against the current government in Portugal was no longer the movement's objective, which sought only "to frame and support the Portuguese people in their struggle against the establishment in Portugal of any totalitarian regime" and "to create and consolidate the necessary conditions for establishing and enabling a pluralistic democracy in Portugal, as understood in Western Europe". (CALVÃO, 1976, p. 212-213). 
As of the end of 1975, the possibility of Spínola returning to Portugal was also raised. It was necessary, however, to create the political and psychological conditions necessary for his return, both in the more influential political and military circles, and in terms of Portuguese public opinion. The weekly newspaper Expresso, in its first issue of 1976, considered that "the correlation of political forces present after November 25 seems to offer Spinolists the possibility of trying to negotiate the return of the former Portuguese army general". This weekly newspaper also stated that "public opinion seems to be the target of a very discreet polling of reactions to his potential return", although the Revolutionary Council had already issued a statement saying that Spínola would be "arrested" as soon as he entered the country, given that there was an arrest warrant out due to his involvement in the events of March 11th. (EXPRESSO, 01/03/1976, p. 8).

Over the first months of 1976 the public statements of General Antonio de Spínola began to change in tone and become more conciliatory. In an interview with the weekly paper Tempo, in January 1976, he sought to completely remove the scenario of a "coup" in Portugal, stating that "it had never been in the spirit or plans of the MDLP to invade Portugal, for the simple reason that its fighting force [...] is the Portuguese people themselves". The idea of "invasion" had been, in fact, "merely a product of speculation and complicity of certain media in service to causes that are not those of our country". The MDLP had never considered the possibility of "triggering a coup." (SPÍNOLA, 1976, p. 403-404).

However, the MDLP felt the need to redefine and clarify its political position and objectives. A document signed by António de Spínola defined it as a "unitary and nonpartisan movement, liberating, humanist, democratic and patriotic". The MDLP was guided only by "national objectives", intending to "bring together all Portuguese people, irrespective of party lines". It aimed to "destroy the tyranny of foreign powers that oppress the country and the people" and create conditions for "collective freedom" of the Portuguese, to never again be "endangered in the future". The movement wanted to establish in Portugal an "authentic democracy", as understood in Western Europe. (SPÍNOLA, 1976, p. 453-455).

The general, however, remained in constant movement. In late January he flew to Paris again and then tried to travel to Spain. But on February 3, 1976, Spanish authorities at the border of Perthus, in the Eastern Pyrenees, did not authorize his entry into the country. The General then had to spend the night in Montpellier, returning to Paris on February 4th. On that occasion the French authorities informed him that he should leave the country by early on the 7 th, "also requiring, however, that he abide by the principle of reservation and neutrality, imposed on all foreigners, with the practical consequence of refraining from any political activity". The French government also decided to expel the general, as he, in his "attempt" to enter Spain, had been accompanied by four people, "some of them [...] using fake passports". This action would have been considered by the 
French authorities as "a political statement", and therefore in violation of the "principle of reservation and neutrality". But the truth is that the French government had also been under strong pressure from the opposition to amend its benevolent position toward António de Spínola's activities. In mid-January, the French Socialist Party had issued a statement in which it protested against the Government's attitude, considered "favorable" to Spínola, and as "a direct aid to the Portuguese counter-revolution raising its head in Lisbon". (EXPRESSO, 02/07/1976, p. 16). Spínola then decided to go to Switzerland, where he arrived on February $7^{\text {th }}$. Upon his arrival, he affirmed that his visit to the country had been for "medical reasons" and that he did not intend to "engage in any political activity". (EXPRESSO, 04/10/1976, p. 1).

\section{Preparing for return}

However, in Portugal, during the first half of 1976, there were new and significant strides towards normalization of political and military life. On February 26, a new Constitutional Agreement Platform was signed, in which political parties and the MFA agreed to eliminate the MFA Assembly, and to significantly reduce the powers of the Revolutionary Council. In early April 1976, the new Constitution was approved, and on the 25th of the same month, the first Parliamentary elections were held, which the Socialist Party won with about 35\% of votes. However, on June 27, Ramalho Eanes was elected President of the Republic with $61.5 \%$ of votes. Shortly after taking office, he nominated Mário Soares as prime minister of the first constitutional government, to commence working on July 23, 1976. The record also shows that in this government, the position of defense minister would be held by one of the men closest to Antonio de Spínola, Colonel Mário Firmino Miguel.

It was in this context that several contacts were made between Portuguese political and military authorities and individuals associated with the MDLP, apparently with two simultaneous objectives: formal dissolution of the MDLP, and the return of Antonio de Spínola to Portugal. The Revolutionary Council in turn publicly stated that it could not prevent Spínola from returning to Portugal, but it guaranteed that the former president would be "immediately arrested" if this were to happen, since there was "sufficient evidence" to hold him responsible for the events of March 11, 1975. (A LUTA, 03/25/1976, p. 16).

Even if Spínola's return was being planned prior to the Parliamentary elections, this scenario was completely set back when in April, 1976 the Portuguese and international press began to release news of his involvement in a conspiracy for armed invasion of Portugal in order to put an end to the alleged control of the country by communist forces. The story began with German journalist Gunter Walraff, who had spent several months in Portugal, managing to infiltrate the 
underground structures of the MDLP and establish contact with members of the movement. In March 1976, he had attracted Spínola himself to a meeting in Dusseldorf, in the Federal Republic of Germany, promising him financial support and military equipment for the MDLP to carry out said invasion. Armed with a tape recorder, Walraff recorded his statements, including acceptance of support and reference to the existence of a hundred thousand men at the disposal of the MDLP to carry out a coup in May or June of 1976. These details would be published by the German magazine Stern and also released by the Portuguese press. Antonio de Spínola and the MDLP even tried to negate the stories, but Stern published photographs of the General disembarking at Dusseldorf airport, as well as the conversation in the restaurant.

The consequences of the "Walraff scandal" would be very serious for General Spínola: expulsion from Switzerland, where he had been since February 1976. The Swiss government evoked "activities carried out from Swiss territory in favor of a clandestine political organization intending to operate in Portugal" (EXPRESSO, 04/10/1976, pg. 1-2.); postponement of his return to Portugal, preventing his presence in the country before the presidential elections of that year; removal of the possibility of the former President of the Republic holding any political office in Portugal. From that point on, his public image would be strongly marked by the whole episode, and his "physical" return to the country in August 1976 would never be equivalent to his "political" return.

Expelled from Switzerland, Spínola departed for Brazil once again, where he arrived on April 10, 1976. The next step would be, necessarily, to dissolve the MDLP. On March 31, Alpoim Calvão sent a long letter to the General, suggesting the "dissolution" of the movement. (CALVÃO, 1976, p. 226-227). Persuaded by Calvão's argument and perhaps by the effects of the "Walraff scandal", General Spínola replied on April 15, 1976 in Rio de Janeiro, with a directive titled "Immediate suspension of MDLP activities." The President of the MDLP now considered that the prospects opened with the next .Parliamentary elections in Portugal had created a "political framework" that made "suspension of MDLP operations" advisable. This suspension of the movement's activities, said Spínola, presumed respect for the results of the "next suffrage" and for a government that was an "effective representative" of popular will. For his part, Spínola would keep "away from operational activities" while guaranteeing his "moral support from those who remained faithful to the ideology and goals that guided the formation of the Movement and encouraged their struggle for the liberation of our country". (CALVÃO, 1976, p. 228-229).

Finally, on April 29, 1976, four days after the Parliamentary elections, Spínola signed the "dissolution order" of the MDLP, from Rio de Janeiro. The holding of elections constituted a "basic factor in the institutionalization of a pluralist democratic system that respects and ensures respect for the sovereign will of the Portuguese people, enshrining it in its fundamental laws". Thus, 
"abiding by the need for political coherence resulting from the ideals that guided the formation of the Movement and drove all of its activity, I hereby decide, having heard the board, to suspend activities of the Democratic Movement for the Liberation of Portugal, with an appeal for all of its members to redirect their efforts to the great task of rebuilding the country, which requires the reconciliation of all Portuguese people”. (SPÍNOLA, 1976, p. 457).

The dissolution of MDLP was a turning point in the preparation for Antonio de Spínola's return to Portugal. In late May of 1976, Spínola told the newspaper Folha de São Paulo, that there was now "no reason" not to return to Portugal. The general appeared convinced that for the moment "the danger of establishing a totalitarian regime" was gone. (JORNAL NOVO, 05/21/1976, p. 8).

\section{Arrival in Lisbon}

In his return trip to Portugal, Spínola first traveled from Rio de Janeiro to New York, where he remained for four days. He then took flight from this city to Lisbon, where he would arrive on August 10, 1976. At Portela airport, the general was immediately arrested and taken to the military prison of Caxias, where he remained for two days to be questioned in proceedings concerning March 11, 1975. Spínola would leave Caxias before dawn on August 12, 1976, (DIÁRIO DE NOTÍCIAS, 08/13/1976, p. 1), although on the 13th he was in the offices of the Joint-Chiefs of the Armed Forces, where he remained throughout the morning, giving an account of MDLP activities, including "its participation in terrorist attacks". (JORNAL NOVO, 08/14/1976, p. 16).

The return of Antonio de Spínola to Portugal elicited mixed reactions in the Portuguese political and military spheres. The elected prime minister, Mário Soares, made a point of emphasizing the fact that Spínola had decided to enter the country "without any pre-arrangements with authorities". Given that there were accusations under "military jurisdiction" against the general, he had of course been arrested and taken to Caxias prison. Soares considered that the "moments chosen" by Spínola to return to Portugal was debatable, but as there was no "crime of banishment in Portuguese society", it was "always better for people to be in Portugal rather than abroad, as perhaps symbols against Portuguese institutions". In a clear warning to the General and his followers, the prime minister also stressed the government and "military authorities" "wanted to fight all forms of conspiracy or subversive actions, by all means necessary, given that we are currently living under a constitutional regime, we have our $1^{\text {st }}$ constitutional government, which is close to completing its discussion of the program in Parliament, and therefore it is expected that all things come to pass within the law and legally without passion or emotion". (JORNAL NOVO, 08/11/1976, p. 7). 
In Parliament, the return of the former President was the topic of debate for several days. On August 12, the Portuguese Communist Party introduced a motion in which it criticized the return of Spínola to Portugal, "at a time when the new democratic regime is taking its first steps". Particularly serious were the "accusations" made against the former president: "attempts at violent coups against the democracy on September 28 and March 11, conspiracies in Portugal and abroad, accountability in training, organizing and executing terrorist activities by MDLP and other counterrevolutionary groups." For all this, the PCP demanded that Spínola be "held fully accountable for his actions" and proposed that Parliament approve a motion in which it lamented that "an invoked failure to investigate the activities of former General Spínola should serve as justification for release" and protested against "the alleged delay in investigations, as some months have passed since many of the terrorist crimes for which the MDLP is directly and indirectly assigned authorship, which organization was headed by former General Spínola". The motion only garnered the votes favoring the PCP, and was therefore not approved. (DIÁRIO DE NOTÍCIAS, 08/13/1976, p. 7).

In the press, Antonio de Spínola's arrival also gave rise to comments and debate. The newspaper Expresso particularly wondered about the timing of the former president's return, claiming that it was at least "curious" that Spínola had returned while the government's program was fully under discussion and at a time when "the first names related to the bombings" perpetrated in 1975 and 1976 had been revealed. These names, the Expresso reminded, pointed "in a preliminary analysis, [...] to MDLP, the organization Spínola affirmed he had recently directed". (EXPRESSO, 08/13/1976, p. 1). The newspaper Jornal Novo also discussed the timing of Spínola's return to Lisbon, considering that it met the criteria of "questionable intent", given that Portugal "was watching with widespread interest the discussion of the government program presented by Mário Soares". Had the moment when "the former general - or someone on his behalf - decided to return" been chosen with "clear" intention "to divert public attention from São Bento to the aristocratic monocled citizen"? The "result of the maneuver was, however, unsuccessful". At the airport, Spínola was met not by the "crowds he had dreamed of, nor the individuals with whom he had once excelled". Instead, it was just the police and the "marching order" to Caxias. In fact, a "cold indifference, if not unrestrained hostility", welcomed Antonio de Spínola on his return to Portugal. In short, "antagonized by the democratic forces, which have not forgotten the recent past, and hated for the reaction and fascism, not forgiven for the political setbacks and betrayal of the New State, Antonio de Spínola will come to realize, bitterly, that political Portugal has no room for him. Only a supreme act of lucidity will beckon to him with the only solution to his problem immediate and voluntary political deactivation, consciously assumed muteness. This will be the best solution for the citizen Antonio de Spínola and the country that he claims to serve. This is the 
only way to convince us that he has learned something from his failures". (JORNAL NOVO, 08/16/1976, p. 6).

\section{Conclusion}

As noted in the preceding pages, during the period in which he remained in exile in Brazil, General Antonio de Spínola engaged in intense political activity, contrary to what he had initially agreed with the Brazilian authorities. Furthermore, the very choice of Brazil as a destination may have fulfilled this calculation: beyond cultural and linguistic affinities and the long tradition of welcoming Portuguese refugees throughout the twentieth century, the current Brazilian regime had since 1964 become the destination, by excellence, of Portuguese political and economic elites who voluntarily or involuntarily left the country in 1974 and 1975.

By leaving Portugal, António de Spínola wrote in 1976, "I took with me the steadfast determination to continue to fight and make sure that the Portuguese people, sooner or later, would realize the betrayal to which they had fallen prey, such as in other critical periods of its history, and would rise massively in a relentless struggle to maintain their homeland a free and independent nation". (SPÍNOLA, 1976, p. 23). In the background, his behavior on Brazilian soil was consistent with these statements. Sheltered in Brazil by personalities like Carlos Lacerda, who provided him with a source of funding, Spínola agreed to lead the MDLP, disseminated its activities and principles, gave interviews and made statements that often extrapolated his status as exile, contacted Brazilian authorities without concealing his purposes, and frequently traveled to Europe and the United States in search of international support for the MDLP.

It seems safe to say that Spínola also benefited from a certain complacency or even support from the Brazilian authorities. In May of 1975, his contact at the Information Center of the Brazilian Navy allowed him to obtain a passport so he could travel through Europe and the U.S. in the months that followed, to obtain political support and funding for the MDLP. To understand this aspect, it must be taken into account that his exile took place in a particularly delicate period of Luso-Brazilian relations. In fact, after March $11^{\text {th }}$ and the radicalization of the political situation in Portugal, reasons for mutual distrust between the two countries abounded. As we have seen, Brazil particularly resented the positions often assumed by Brazilian political exiles in Portugal, and the way the Portuguese press had portrayed the dictatorial regime in force in Brazil since 1964.

It was also from Brazil, in August 1975, that Spínola wrote the aforementioned "open letter" to President Costa Gomes, an initiative which later that month led to an official protest by Portuguese diplomacy. When he returned the following month to visit France, the Brazilian media itself recognized that the General sought to establish true "international brigades" to take action within a few weeks. (RÁDIO JORNAL DO BRASIL). Protests from the Portuguese authorities, as 
already mentioned, were frequent but to little avail. As noted by Thiago Carvalho, the truth is that during the "revolutionary drift" in Lisbon, "the channels of bilateral dialog were blocked". Hence "Brasilia's tolerance of the former President's conspiratorial activities sought to embarrass the Portuguese government and force it to control the political manifestations and appeals made against the Brazilian military regime in its territory". In other words, although the Brazilian government had not contemplated direct support for Spínola's conspiratorial activities, the truth is that he was assured a certain "freedom of action as long as opposition to the Brazilian government in Portugal was not silenced". (CARVALHO, 2009, p. 116).

Spínola's activities while in exile in Brazil were so egregious that even the United States, through its ambassador in Lisbon, Frank Carlucci, expressed concern, advising Brazilian authorities not to directly support the general. When Spínola visited the United States in November 1975, the U.S. government saw fit to inform the Brazilian government that it had not invited the general, and that it had no involvement in this trip.

Once the political situation in Portugal was normalized through November $25^{\text {th }}$, the adoption of the 1976 Constitution, and the parliamentary and presidential elections, relations between the two countries began a long journey to normalization, culminating in a visit by Mário Soares to Brazil in December 1976. General Spínola also retreated from his activities, first by redefining the goals of the MDLP, and then enacting its eventual dissolution in April 1976, days after the German journalist Gunter Walraff had reported Spínola's presence in Europe seeking support for his movement.

Spínola's return to Portugal took place in August 1976, after nearly eighteen months of exile in Brazil. During this time, as the general said, he never truly experienced the "nostalgia of exile". The "nostalgia" he actually came to feel was for living in a "prosperous, free, independent Portugal, respected by countries of the free world". Until that should come to pass, Spínola said in January of that same year, "I prefer the current situation of exile rather than living in exile in my own country". (SPÍNOLA, 1976, p. 409).

\section{References}

A LUTA. Lisboa, dez. 1975; mar. 1976.

BERNARDO, Manuel A. Memórias da revolução. Portugal, 1974-1975. Lisboa: Editora Prefácio, 2004.

CALVÃO, Alpoim. De Conakry ao MDLP. Dossier Secreto. Lisboa: Editorial Intervenção, 1976. 
CARVALHO, Thiago. Do lirismo ao pragmatismo. A dimensão multilateral das relações LusoBrasileiras (1974-1976). Lisboa: Instituto Diplomático, 2009.

CEREZALES, D. Palacios. O poder caiu na rua. Crise de Estado e acções colectivas na Revolução Portuguesa, 1974-1975. Lisboa: Imprensa de Ciências Sociais, 2003.

DÂMASO, Eduardo, A invasão spinolista. Lisboa: Fenda, 1997.

DIÁRIO DE NOTÍCIAS. Lisboa, mar./ago./set. 1975.

EXPRESSO. Lisboa, jan./abr./ago. 1976.

FREIRE, Américo. Ecos da Estação Lisboa. O exílio das esquerdas brasileiras em Portugal. Sociologia, Problemas e Práticas, n. 64, p. 37-57, 2010.

JORNAL NOVO. Lisboa, mai./ago. 1976.

PAUlO, Heloísa. Aqui também é Portugal: a colónia portuguesa do Brasil e o Salazarismo. Coimbra: Quarteto, 2000.

REPÚBLICA. Lisboa, mar. 1974; dez. 1975.

REZOLA, M. Inácia. António de Spínola. Fotobiografia. Lisboa: Museu da Presidência da República, 2006.

RODRIGUES, Luís N. Spínola. Lisboa: Esfera dos Livros, 2010.

SILVA, Douglas M. da. A oposição ao Estado Novo no exílio brasileiro 1956-1974. Lisboa: ICS, 2006.

SPÍNOLA, António de. Ao serviço de Portugal. Lisboa: Ática/Livraria Bertrand, 1976.

THE NEW YORK TIMES. Nova Iorque, 24/05/1975, p. 7.

\footnotetext{
Notes

${ }^{1}$ Fundação Getúlio Vargas. CPDOC/FGC, AAS, mre/rb, 1975.05.23, Folder Pasta III, Carta de António de Spínola a Ernesto Geisel, Mar. 26, 1975.

${ }^{2}$ Spínola's Day in Argentina. Telegram from the U.S. Embassy in Buenos Aires to the U.S. State Department dated Mar. 17, 1975.

${ }^{3}$ Spinola's Day in Argentina. Telegram from the U.S. Embassy in Buenos Aires to the U.S. State Department dated Mar. 17, 1975.

${ }^{4}$ Asylum For General Spinola. Telegram from the U.S. Embassy in Santiago to the State Department on Mar. $15,1975$.

${ }^{5}$ Fundação Getúlio Vargas. CPDOC/FGC, AAS, mre/rb, 1975.05.23, Pasta III, Carta de António de Spínola a Ernesto Geisel, Mar. 26, 1975.

${ }^{6}$ Designation derived from the name of Vasco Gonçalves, prime minister of Portugal between July 1974 and late August 1975.

7 Fundação Getúlio Vargas. CPDOC/FGC, AAS, mre/rb, 1975.05.23, Pasta III, Informação 0065/75 do Centro de Informações da Marinha, May 19, 1975.

${ }^{8}$ French Perceptions on Portugal. Telegram from the U.S. Embassy in Paris to the State Department, Jul. $25,1975$.

${ }^{9}$ Portuguese React To Spinola Letter. Telegram from the U.S. Embassy in Brasilia to the State Department on August $22,1975$.
} 
${ }^{10}$ Política Externa Brasileira. Otimista. Discurso de Azeredo da Silveira, 23 de agosto de 1975. Resenha de Política Exterior do Brasil, n. 6, p. 51-55, jul., ago. e set., 1975,. Available at: http://mundorama.net/2008/02/29/rpeb-julhoagosto-e-setembro-no-61975/. Accessed on Oct. 5, 2009.

${ }^{11}$ Foreign Minister's Speech on Latin America, Africa, World Economic Order, and Portugal. Telegram from the U.S. Embassy in Brasilia to the State Department on Aug. 27, 1975.

${ }^{12}$ Fundação Getúlio Vargas. CPDOC/FGC, AAS, mre/rb, 1975.05.23, Pasta III, Carta da Embaixada de Portugal em Brasília ao governo brasileiro, Aug. 30, 1975.

${ }_{13}^{13}$ General Spinola Arrives in Paris. Telegram from the U.S. Embassy in Paris to the State Department on Sep. 4, 1975.

${ }^{14}$ General Spinola Arrives in Paris. Telegram from the U.S. Embassy in Paris to the State Department on Sep. 4, 1975.

${ }^{15}$ Spinola. Telegram from the U.S. Embassy in Lisbon to the State Department, on Sep. 11, 1975.

${ }^{16}$ Updated Talking Points on Portugal for Deputy Secretary's Use in Meeting With Prime Minister Palme. Telegram from the State Department to the U.S. Embassy in Stockholm, Sep. 12, 1975.

${ }^{17}$ General Spinola and the Portuguese Exiles. Telegram from the State Department to a number of United States diplomatic missions on Sep. 13, 1975.

${ }_{18}^{18}$ General Spinola. Telegram from the U.S. Embassy in Lisbon to the U.S. Embassy in Brasilia on Sep. 17, 975.

${ }^{19}$ General Spinola Plans Visit To Washington. Telegram from the State Department to the U.S. Embassy in Lisbon, on Nov. 13, 1975.

${ }^{20}$ General Spinola Plans Visit To Washington. Telegram from the State Department to the U.S. Embassy in Lisbon, on Nov. 13, 1975.

${ }^{21}$ Spinola's Planned Visit To Washington. Telegram from the U.S. Embassy in Lisbon to the State Department on Nov. $15,1975$.

${ }^{22}$ Conversation With President Costa Gomes. Telegram from the U.S. Embassy in Lisbon to the State Department on Nov. 20, 1975.

${ }^{23}$ Portugal: Spinola's Visit to the U.S. Telegram from the U.S. embassy in Madrid to the State Department on Nov. 18, 1975.

${ }^{24}$ Spinola's Visit To US. Telegram from the U.S. Embassy in Brasilia to the State Department on Nov. 19, 1975.

${ }^{25}$ Spinola's Planned Visit To Washington. Telegram from the U.S. Embassy in Paris to the State Department on Nov. $18,1975$.

${ }^{26}$ Press Guidance: Spinola Visit. Telegram from the State Department to the U.S. Embassy in Lisbon, on Nov. 18, 1975.

Luís Nuno Rodrigues holds a $\mathrm{PhD}$ in American History from the University of Wisconsin and in Modern and Contemporary History (specialization in History of International Relations in the Contemporary Era) from ISCTE - Lisbon University Institute. He is an Associate Professor at the History Department of ISCTE-IUL, where he coordinates the doctoral program in History, Defense and International Relations; he is a researcher at the Center for International Studies of ISCTE-IUL and Director of the Portuguese Journal of Social Science.

Received on $08 / 04 / 2014$

Approved on 09/05/2014 